\title{
The dependency of the size-growth relationship of Norway spruce (Picea abies [L.] Karst.) and European beech (Fagus sylvatica [L.]) in forest stands on long-term site conditions, drought events, and ozone stress
}

\author{
Hans Pretzsch $\cdot$ Jochen Dieler
}

Received: 17 September 2010/Revised: 8 October 2010/Accepted: 21 October 2010/Published online: 11 November 2010

(C) The Author(s) 2010. This article is published with open access at Springerlink.com

\begin{abstract}
Against a backdrop of increasing climate change, the effects of site conditions, drought events and ozone stress on the size-growth relationship in Norway spruce (Picea abies [L.] Karst.) and European beech ( $\mathrm{Fa}$ gus sylvatica [L.]) stands are analyzed. The size-growth relationship is represented by a straight line defined by intercept and slope of a simple linear equation with stem diameter at height $1.30 \mathrm{~m}$ as independent variable and annual stem diameter increment at height 1.30 as dependent variable. On the basis of 64 long-term experimental plots dating back to 1871 and representing an ecological gradient from fertile to poor sites, it is shown that poorer sites exhibit shallower slopes of the linear size-growth relationships than fertile sites. Annual measurements of the size-growth relationship, including the extremely dry years of 1976 and 2003, also showed that lower stand growth rates result in shallower size-growth relationship slopes. By comparing stands with and without experimental twiceambient ozone exposure between 2000 and 2007, it was found that ozone stress can significantly reduce the slope of the size-growth relationship. This indicates that limiting site condition, whether acute or chronic in nature, distinctly reduces the superiority of tall trees, and that a lower degree of resource limitation increases the steepness of the sizegrowth relationship. The causes for this behavior and the consequences for stand dynamics, silvicultural treatment and prognostication by models are discussed.
\end{abstract}

Communicated by U. Luettge.

H. Pretzsch $(\bowtie) \cdot$ J. Dieler

Chair for Forest Growth and Yield Science,

Technische Universität München, Munich, Germany

e-mail: hans.pretzsch@1rz.tum.de
Keywords Size-asymmetric growth · Diameter increment - Competition - Resource partitioning . Limitation $\cdot$ Allocation principle $\cdot$ Stand structure

\section{Introduction}

The principles of resource and biomass growth distribution between neighboring trees in a stand and the change of this distribution due to stress are important factors when scaling up from individual tree to stand and ecosystem dynamics. However, while the allocation principles at an individual plant level have been well documented and studied (e.g., Niklas 1994; Landsberg 1986; Mäkelä and Hari 1986) and the growth dynamics at a stand level are well described on the basis of the average tree (e.g., Assmann 1970; Oliver and Larson 1996; Pretzsch 2010), insight into the resource and growth distribution between the trees of a stand or cohort and its dependency on site conditions is still limited (Schwinning and Weiner 1998). Analysis at an individual plant level, considering allocation principles and plant responses under stress, can produce evidence of a stress response. However, far reaching conclusions on the relevance of such reactions and the performance at a stand level require further research into tree interactions, competition and possible compensation effects between trees under stress. The reaction pattern of stands or cohorts is more than just an individual tree response and, thus, cannot be inferred from trees growing solitarily in greenhouses (Matyssek et al. 2005).

The insight into the dependency of the size-growth relationship from environmental conditions is of particular interest because tree growth and stand dynamics are increasingly affected by trends of changing growing conditions (Spiecker et al. 1996) and stress events (Jentsch 
et al. 2007; Matyssek and Sandermann 2003; Pretzsch et al. 2010). The effects of site conditions, disturbances and stress events on tree as well as stand growth as a whole have frequently been analyzed empirically (Schweingruber et al. 1986; Röhle 1987), summarized (Pretzsch 1999), and prognosticated by models (Bugmann et al. 1997; Pretzsch et al. 2008). The reaction pattern of individual tree growth spans from growth acceleration, where the former limitation is remedied (Pretzsch 1999), to gradual decreases of vitality by long-term deposition (Elling 1993), abrupt growth losses (Utschig 1989) or even die-back (Röhle 1987). The reaction pattern at a stand level is correspondingly wide, site-dependent (Pretzsch 2009, pp. 543-550), and subject to considerable variation between stands. Growth rates may increase on formerly poor sites, or sites with decreasing air pollutants (Mielikäinen and Timonen 1996). Sites which become water limited or suffer from absorption of long-range emissions or summer drought show severe declines in growth (Beierkuhnlein and Foken 2008). Numerous investigations have thus contributed to a sound understanding of tree growth and of cumulative stand growth rates in dependence on trees species, site conditions and types of stress.

In contrast, the understanding of the distribution of resources and growth between competing individuals in a stand is still rather limited. Depending on the respective limiting factor (e.g., light, water, nutrients) the division of resources between individuals in a stand may be entirely size asymmetric, whereby the larger plants receive all the contested resources. The opposite, borderline case is a completely symmetric division of resources, in which all plants, irrespective of size, obtain the same amount of resources. Within these two scenarios, Schwinning and

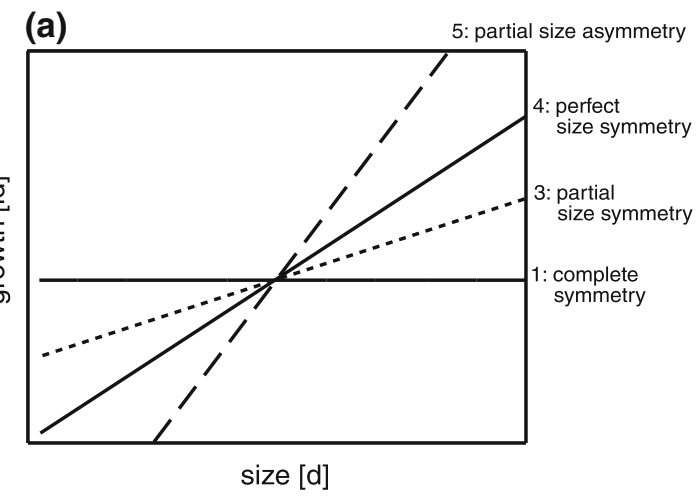

Fig. 1 Hypotheses on the relationship between plant size (represented by stem diameter $d$ at height $1.30 \mathrm{~m}$ ) and absolute growth rate (represented by annual stem diameter increment id at height $1.30 \mathrm{~m}$ ). a Different linear relationships between plant size and growth and b non-linear relationships between size and growth. Line 1 represents the more theoretical case of complete symmetric size-growth relationship where all plants receive the same budget of growth irrespective of their size. Line 2 displays non-linear concave size-
Weiner (1998) distinguish between partial size-symmetric, perfect size-symmetric and partial size asymmetric distribution of resources. As resource distribution between individuals is difficult to measure, but assumed to be proportional to the absolute growth rate, the size-growth relationship is used as a proxy for the size-resource relationship (e.g., Hara 1993; Pretzsch and Biber 2010; Wichmann 2001, 2002; Weiner 1990). The stem diameter increment (id $=$ absolute growth rate in a defined period, such as 1 year) was thus plotted against stem diameter ( $d=$ diameter at tree height $1.30 \mathrm{~m}$ ) at the beginning of the respective period. Figure 1 displays a set of linear (lines 1, 3, 4, and 5) and non-linear (lines 2, 6) size-growth relationships (adapted from Weiner 1990). A steeper slope indicates higher growth rates and favored resources supply of tall trees in the stand. The case of complete sizeasymmetry, indicated by a line parallel to the $y$-axis (slope $=\infty$; a sub-cohort of large plants receives all growth), is solely of academic interest and not integrated in Fig. 1. Note that all relationships in Fig. 1a are linear. However, only line 4 represents a linear and proportional increase of absolute growth rate with increasing size, meaning only in this case is the relative growth rate equal for all individuals.

Complete symmetry (Fig. 1a, line 1) means that growth and resources, which competitors receive, are independent of their size. Tendency towards complete symmetry (line 1) or partial size-symmetry (Fig. 1a, line 3; Fig. 1b, line 2) is assumed to prevail under limitation by below-ground resources (water and mineral nutrients), as they are difficult to preempt by larger individuals (Kuijk et al. 2008). Partial or strong size-asymmetry (Fig. 1a, line 5; Fig. 1b, line 6) means that larger individuals obtain a disproportionately

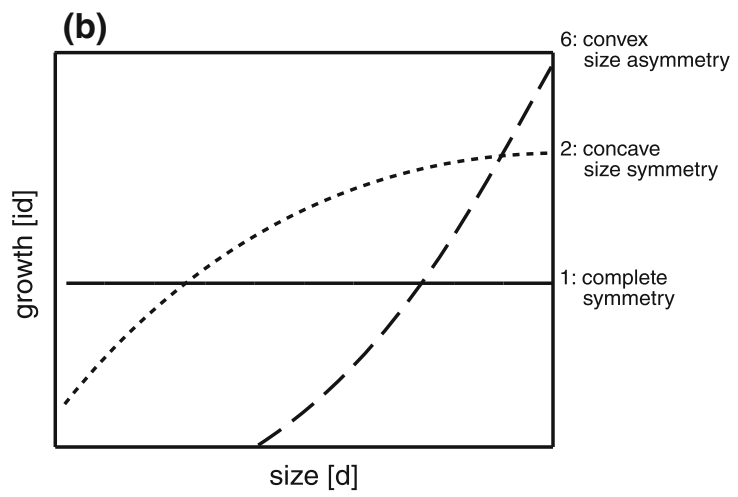

symmetry where growth increases degressively with size. Line 3 reflects partial size-symmetry where growth increases linearly with size. Line 4 represents perfect size-symmetry and means that the amount growth increases proportionally with size. Line 5 stands for partial size-asymmetry where growth increases linearly with size. Finally, line 6 represents non-linear convex size-asymmetry as the growth increases progressively with size 
higher share of resources and growth. This mode of sizegrowth relationship can be expected on rich sites where light is the limiting factor of tree growth and, as a vectorial resource, preemptible by the larger individuals (Canell and Grace 1993; Weiner and Thomas 1986).

A number of studies show that the mode of competition and the size-growth relationship can change spatially along ecological gradients (Hara 1993; Pretzsch and Biber 2010) as well as temporally with stand development (Thomas and Weiner 1989; Weiner and Thomas 1986). Other studies have revealed a change from size-symmetric competition in dry years when below-ground resources are scarce, to size-asymmetry in moist years when light becomes the limiting factor (Wichmann 2001).

On long-term experimental plots in forest stands, the manner in which chronic and acute limiting site conditions affect the size-growth relationship between neighboring trees was analyzed in this study. Norway spruce (Picea abies [L.] Karst.) and European beech (Fagus sylvatica [L.]) were analyzed, as they represent the most important species for Central European forestry (Bundesministerium für Ernährung and Landwirtschaft und Verbraucherschutz 2005; FAO 2005). Specifically, the following three questions were addressed:

(i) On the basis of 64 long-term experimental plots, dating back to 1871 and representing an ecological gradient from excellent to poor sites, we question how the site index affects the size-growth relationship within the stands.

(ii) Using the size-growth relationship between 1972 and 2007, including the extremely dry years 1976 and 2003 we ask how whole stand growth rate and whether conditions affect the size-growth relationship.

(iii) On the basis of a dataset of the Kranzberg ozone fumigation experiment (Matyssek et al. 2010) between 2000 and 2007 we scrutinize how the size-growth relationships in stands is affected by ozone exposure.

\section{Materials and methods}

The analysis of the size-growth relationship is based on the diameter at breast height as the independent size variable (Fig. 1, $x$-axis). As the dependent variable (Fig. 1, $y$-axis), the mean periodical annual diameter increment was used for the long-term plots (i) and the current annual diameter increment was used for analyzing the effect of weather conditions and ozone-effects (ii and iii). Throughout the text the term "size-growth relationship" is used when we refer to the growth partitioning between trees in a stand in general, while we use the term "diameter-diameter increment relationship" when we address the methodological approach and variables which we used to study the growth partitioning principle. The following three sections outline the samples and methods used to answer questions (i), (ii) and (iii).

The approach to question (i) was as follows: Long-term experimental plots were selected from pure stands of Norway spruce and European beech in the lowland and sub-alpine forests in the German states of Bavaria and Rhineland Palatinate. The following 12 experiments were used for Norway spruce: Sachsenried 3, Ottobeuren 8, Eglharting 72, 73, Denklingen 84, Mitterteich 101, Fichtelberg 227, Feuchtwangen 261, Eurach 605, Sachsenried 607, Weißenburg 613, and Wackersdorf 619. For European beech, the following four experiments were used: Mittelsinn 25, Hain 27, Starnberg 91, and Mitterteich 101. All are spacing or thinning experiments and they comprise a number of plots with different stand densities set by initial spacing and/or continuous thinning. The names indicate the experiment's locations and their numbers in the network of long-term experiments established in forests in Germany since 1871. Most of them are well-known and frequently quoted experiments for other research into forest science (e.g., Assmann 1970; Pretzsch 2009). As this analysis requires the size-growth relationship and its dependency on limiting factors, experiments which represent a broad range of site conditions were selected. In order to understand and eliminate the effect of stand age and stand density on the size-growth relationship, a robust sampling method ensuring sufficient representation of stand age and stand density was employed. Exclusively plots free of mixture and unwanted disturbances (e.g., bark beetle, ice-breakage, and wind-throw) were included. By choosing plots with a sample size of more than 50 trees and successive survey periods covering lengths $>5$ years, a robust database for the subsequent statistical analysis of the size-growth relationship was ensured.

Table 1 summarizes the number of experiments and plots, the year of establishment, survey period, site conditions, and growth characteristics. The year of establishment ranges between 1871 in case of the oldest thinning experiments in European beech and 1988 in case of the newer combined spacing and thinning experiments in Norway spruce. The spectrum of site conditions is characterized by the range of maximum height $\left(h_{\mathrm{o}}\right)$ that Norway spruce and European beech achieve at an age of 100 years.

The analysis of the size-growth relationship is based on the relationship between the diameter at breast height ( $d$ in $\mathrm{mm}$ ) at the beginning of the growth period and the mean annual diameter increment (id in $\mathrm{mm}$ ) within the period. In order to assign each of the $d$-id relationships to one of the 
Table 1 Essentials of the longterm experiments (applied for answering question i): year of establishment differs between 1871 in case of the oldest and 1988 in case of more recently established experiments.

Minimum, maximum, mean and standard deviation of stand age (age), height of the quadratic mean diameter of the 100 tallest trees per hectare $\left(h_{\mathrm{o}}\right)$, stand density index (SDI), quadratic mean diameter of the stand $\left(d_{\mathrm{q}}\right)$, and mean annual diameter increment of the quadratic mean diameter tree $\left(\mathrm{id}_{\mathrm{q}}\right)$. Site index $h_{\mathrm{o}}$ refers to yield table Assmann and Franz (1963) for Norway spruce and Schober (1967) for European beech

\begin{tabular}{|c|c|c|}
\hline Variable & Norway spruce & European beech \\
\hline Number of experiments (sum) & 12 & 4 \\
\hline Year of establishment (range) & $1887-1988$ & 1871-1966 \\
\hline Number of plots per experiment (range) & $2-13$ & $2-5$ \\
\hline Number of survey periods (sum) & 286 & 98 \\
\hline Height above sea level (m) & $380-830$ & $400-645$ \\
\hline Mean annual temp. $\left({ }^{\circ} \mathrm{C}\right)$ & $5.9-8.0$ & $5.5-7.5$ \\
\hline Mean annual precip. $\left(\mathrm{mm}\right.$ year $^{-1}$ ) & $668-1,204$ & $893-1,080$ \\
\hline Number of observations & 54,888 & 13,192 \\
\hline Age $( \pm \mathrm{SD})$ (years) & $61.8( \pm 25.0)$ & $99.0( \pm 36.4)$ \\
\hline Age min-max (years) & $16-119$ & $43-169$ \\
\hline$h_{\mathrm{o}}$ at age 100 mean $( \pm \mathrm{SD})(\mathrm{m})$ & $35.7( \pm 6.1)$ & $33.0( \pm 4.5)$ \\
\hline$h_{\mathrm{o}}$ at age $100 \min -\max (\mathrm{m})$ & $19.5-48.7$ & $27.5-38.0$ \\
\hline SDI mean $( \pm \mathrm{SD})\left(\right.$ trees $\left.^{-1}\right)$ & $1,056( \pm 286)$ & $704( \pm 138)$ \\
\hline SDI min-max (trees $\left.\mathrm{ha}^{-1}\right)$ & $283-1872$ & $434-950$ \\
\hline$d_{\mathrm{q}}$ mean $( \pm \mathrm{SD})(\mathrm{mm})$ & $239.3( \pm 95.0)$ & $271.9( \pm 112.1)$ \\
\hline$d_{\mathrm{q}} \min -\max (\mathrm{mm})$ & $47.8-496.9$ & $94.1-564.4$ \\
\hline $\mathrm{id}_{\mathrm{q}}$ mean $( \pm \mathrm{SD})(\mathrm{mm})$ & $2.97( \pm 1.57)$ & $2.17( \pm 0.76)$ \\
\hline $\mathrm{id}_{\mathrm{q}} \min -\max (\mathrm{mm})$ & $0.30-11.95$ & $0.62-5.28$ \\
\hline
\end{tabular}

six basic relationships shown in Fig. 1, the $d$-id value pairs were fitted by both of the following models:

$i_{d}=a_{0}+a_{1} \times d+\varepsilon$

$i_{\mathrm{d}}=b_{0}+b_{1} \times d+b_{2} \times d^{2}+\varepsilon$.

with id increment in diameter $(\mathrm{mm}) ; d$ diameter $(\mathrm{mm}) ; a_{0^{-}}$ $a_{1}$ and $b_{0}-b_{2}$, regression coefficients; $\varepsilon$ random error.

When $b_{2}$ in Eq. 2 differs significantly from zero, it is evident that the relationship is non-linear and we can distinguish two different outcomes; a positive $b_{2}$, which indicates a more than proportional increase (Fig. 1b, line 6 ), and a negative $b_{2}$, which indicates a less than proportional increase of increment with size (Fig. 1b, line 2). $b_{2}=0$ indicates a linear $d$-id relationship, represented by Eq. 1. In this case, four distinctly different linear archetypes can be distinguished (Eq. 1): $a_{1}$ not significantly different from zero indicates a complete symmetric sizegrowth relationship (Fig. 1a, line 1). Perfect size-symmetry occurs when $a_{0}$ is close to 0 , forming a straight line through the origin (Fig. 1a, line 4). A less than proportional increase of increment with size (Fig. 1a, line 3) is indicated by $a_{0}>0$ and a more than proportional increase (Fig. 1a, line 5) is indicated by $a_{0}<0$. Each of the analyzed sizegrowth relationships was assigned to one of the six basic curve types.

The vast majority of the $d$-id curves proved to be linearly increasing for all four species (Fig. 1a, lines 3, 4, or 5). Non-linear, less than proportional increases (Fig. 1b, line 2) occurred in $12 \%$ of Norway spruce and $1 \%$ of European beech cases, while non-linear, more than proportional increases (Fig. 1b, line 6) occurred in 6\% of Norway spruce and $1 \%$ of European beech cases. In $2 \%$ of Norway spruce and $1 \%$ of European beech cases the $d$-id relationship ran parallel with the $x$-axis (Fig. 1a, line 1). Since the $d$-id relationship followed a straight line in $82 \%$ of Norway spruce and $98 \%$ of European beech cases (Fig. 1a, lines 3, 4 , or 5), all relationships were fitted with the simple linear model (Eq. 1). This meant that a minority of non-linear diameter-diameter increment relationships were fitted with a straight line in order to maintain consistency in the subsequent analyses.

The application of a linear model should be taken into consideration when interpreting the results, even in cases where a non-linear model might seem more appropriate. When compared with predictions of the linear model, the share of the growth of the larger trees is higher in the upper range of the $a_{1}$ parameter (Eq. 1), and lower than predicted in the lower range. This shows that the results of the linear fit represent somewhat conservative estimations of the relative share of growth and resources of the large trees when compared with their smaller neighbors.

The slope defined by the coefficient $a_{1}$ from Eq. 1 is subsequently arranged as dependent on available stand characteristics (Eq. 3).

$a_{1}=c_{0}+c_{1} \times h_{\mathrm{o}}+c_{2} \times \mathrm{SDI}+c_{3} \times d_{\mathrm{q}}+\varepsilon$

The signs and absolute values of the parameters $c_{1}, c_{2}$ and $c_{3}$ reveal how site quality $h_{\mathrm{o}}(\mathrm{m})$, stand density SDI $\left(\mathrm{N} \mathrm{ha}^{-1}\right)$ and stage of stand development $d_{\mathrm{q}}(\mathrm{cm})$ determine the growth distribution among individuals. In order to scrutinize the impact of site conditions on the slope 
of the diameter-diameter increment relationship, the yield characteristics, specifically dominant height at age $100\left(h_{\mathrm{o}}\right)$ (a proxy for site quality), stand density index (SDI) (Reineke 1933; Pretzsch and Biber 2005), and quadratic mean stand diameter $\left(d_{\mathrm{q}}\right)$ were specified for each plot and survey. Thus in creating this model and including $d_{\mathrm{q}}$, the well-known fact that the slope of the size-growth relationship decreases with increasing average tree size was taken into consideration (Prodan 1965, pp. 474-476). In order to keep the decimal places of parameters $c_{0}$ to $c_{3}$ low, the independent variables $\left(h_{\mathrm{o}}\right.$, SDI and $d_{\mathrm{q}}$ ) were divided by 1,000 before being applied in the regression.

The approach to question (ii) was as follows: In order to analyze the effect of alternating annual growing conditions and drought on the size-growth relationship, the long-term experimental plot FRE 813/1, which is not included in the dataset applied for question (i), was selected. The number behind the slash in FRE 813/1 means that we deal with plot 1 of experiment FRE 813.

The experimental plot FRE $813 / 1$ is located at $11^{\circ} 39^{\prime} 42^{\prime \prime} \mathrm{E}, 48^{\circ} 25^{\prime} 12^{\prime \prime} \mathrm{N}$, in the ecological region described by Kreutzer and Foerst (1978) as Tertiary Hill Country, Upper Bavarian Hill Country ("Wuchsbezirk 12.8, Oberbayerisches Tertiärhügelland"), in the southern region of the German state of Bavaria, near the town of Freising and approximately $35 \mathrm{~km}$ northeast of Munich (Pretzsch et al. 1998). At an altitude of $490 \mathrm{~m}$, the stand stocks on parabrown soil, based on loess and tends to pseudo-gley. The potential natural vegetation would be a Galio-odoratiFagetum association, dominated by European beech (Pretzsch and Schütze 2009). Daily observations of precipitation $(P, \mathrm{~mm})$ and temperature $\left(T,{ }^{\circ} \mathrm{C}\right)$ were collected by the German Weather Service (Deutscher Wetterdienst, DWD) from the Weihenstephan-Dürnast weather station. The respective climate conditions are shown in Table 2 and Fig. 5.

The plot is part of the Kranzberg crane experiment, and details are published by, among others, Matyssek et al. (2010), Pretzsch et al. (1998) and Werner and Fabian (2002). The experimental design comprises pure stands of Norway spruce and European beech and, separated by a stand section in which both species are mixed. From the three subplots (pure spruce, pure beech and mixed spruce/ beech) the pure stands, which represent very good to excellent site conditions for both species, are used. The pure Norway spruce and European beech plots used in this experiment are best suited to the agenda of this study, as records of annual diameter and diameter increment for the period 1972-1980 (retrospectively with increment cores) and 1999-2007 (monitored continuously by permanently installed and monthly read girth tapes at $1.30 \mathrm{~m}$ stem height; annual increment in diameter is represented by the difference of two consecutive January measurements) are readily available. The two time periods include the extremely dry years of 1976 and 2003. The ages at the end of the measurement period in 2007 were determined as $56 \pm 2$ years for Norway spruce, and $66 \pm 4$ years for European beech. For more characteristics of the samples see Table 2.

For each of the years covered in this study, the $d$-id relationship was fitted by a linear regression

$\mathrm{id}=e_{0}+e_{1} \times d+\varepsilon$

with id, diameter increment in $\mathrm{mm}$ at height $1.30 \mathrm{~m} ; d$, diameter in $\mathrm{mm}$ at height $1.30 \mathrm{~m}$ and the regression coefficients $e_{0}$ and $e_{1}$ for further evaluation. By continuing with regression coefficients $e_{0}$ and $e_{1}$ in Eq. 4, we deviate from the alphabetical order to avoid confusion of parameters $d_{0}$ or $d_{1}$ with diameter $\mathrm{d}$. In order to analyze whether any interdependency between the size-growth relationship and the annual growing conditions exists, two types of independent analyses were carried out.

In the first analysis, the annual stand volume growth was used as a proxy for the annual growing conditions. Due to the short length of the analyzed growth periods it was not necessary to correct for any age trend. The regression coefficient $e_{1}$ of the size-growth relationship was regressed on the annual stand growth rate in volume (ivol, $\mathrm{m}^{3} \mathrm{ha}^{-1}$ year $^{-1}$ )

$e_{1}=f_{0}+f_{1} \times$ ivol $+\varepsilon$

as it represents the overall stand level productivity, and the slope $e_{1}$ indicates how this growth is partitioned among the trees. In order to keep the decimal places of parameters $f_{1}$ low the independent variable ivol was divided by 100 before inserting into the regression.

In the second step, the dependency of the slope of the diameter-diameter increment relationship on annual weather characteristics such as precipitation $\left(P, \mathrm{~mm} \mathrm{year}^{-1}\right)$, temperature $\left(T,{ }^{\circ} \mathrm{C}\right)$ and deduced variables such as potential evapotranspiration (pET, mm year ${ }^{-1}$ ) and climate water balance $\left(\mathrm{CWB}, \mathrm{mm}\right.$ year $^{-1}$ ) during growing season was analyzed using the Pearson correlation. The significance and mode of statistical relationship between these independent variables and $e_{1}$ indicate how annual $d$-id relationships depend on annual climate conditions. In addition, an attempt was made to identify any relationship between the annual slopes of the $d$-id relationship and the climate variables by pairwise comparisons using the Pearson correlation and the Gleichlaeufigkeit score (GLK) (Eckstein and Bauch 1969). GLK values close to 1 indicate that the two time series follow the same pattern in terms of their annual trends, while lower GLK values indicate less synchronicity between the compared time series. GLK scores were calculated using the R software package "dplR" (R development Core Team 2009). In order to reveal any 
Table 2 Characteristics of the two sampled pure stands of Norway spruce and European beech (applied for answering question ii) shown for the survey periods 1972-1980 and 1999-2007 separately

\begin{tabular}{|c|c|c|c|c|}
\hline \multirow[t]{2}{*}{ Variable } & \multicolumn{2}{|c|}{ Period 1972-1980 } & \multicolumn{2}{|c|}{ Period 1999-2007 } \\
\hline & N. spruce & E. beech & N. spruce & E. beech \\
\hline Tree number first year $\left(\mathrm{n} \mathrm{ha}^{-1}\right)$ & 2,466 & 786 & 877 & 1,374 \\
\hline Mean height first year (m) & 12.5 & 14.8 & 24.7 & 24.3 \\
\hline Stand age first year (year) & 17 & 35 & 44 & 62 \\
\hline Site index $h_{\mathrm{o}}$ at age $100(\mathrm{~m})$ & 45 & 35 & 45 & 35 \\
\hline Number of trees $(n)$ & 61 & 32 & 59 & 43 \\
\hline Mean diameter $( \pm \mathrm{SD})(\mathrm{mm})$ & $148( \pm 39)$ & $143( \pm 44)$ & $277( \pm 81)$ & $223( \pm 74)$ \\
\hline Min-max diameter (mm) & $59-263$ & $64-269$ & $107-522$ & $81-449$ \\
\hline Diameter growth $( \pm \mathrm{SD})\left(\mathrm{mm} \mathrm{year}^{-1}\right)$ & $4.8( \pm 2.0)$ & $3.6(1.8)$ & $3.5( \pm 2.6)$ & $2.1( \pm 2.0)$ \\
\hline Min-max diameter growth $\left(\mathrm{mm} \mathrm{year}^{-1}\right)$ & $0.4-11.2$ & $0.6-10.5$ & $0.0-14.6$ & $0.0-9.9$ \\
\hline Annual stand growth $( \pm \mathrm{SD})\left(\mathrm{m}^{3} \mathrm{ha}^{-1}\right.$ year $\left.^{-1}\right)$ & & & $27.9( \pm 6.0)$ & $25.1( \pm 4.6)$ \\
\hline$P$ veg. per. $( \pm \mathrm{SD})\left(\mathrm{mm} \mathrm{year}^{-1}\right)$ & $438( \pm 101)$ & & $440( \pm 100)$ & \\
\hline$P$ year $( \pm \mathrm{SD})\left(\mathrm{mm} \mathrm{year}^{-1}\right)$ & $790( \pm 129)$ & & $868( \pm 163)$ & \\
\hline$T$ veg. per. $( \pm \mathrm{SD})\left({ }^{\circ} \mathrm{C}\right)$ & $14.3( \pm 0.6)$ & & $15.7( \pm 1.0)$ & \\
\hline$T$ year $( \pm \mathrm{SD})\left({ }^{\circ} \mathrm{C}\right)$ & $7.6( \pm 0.5)$ & & $8.3( \pm 0.5)$ & \\
\hline pET veg. per. $( \pm \mathrm{SD})\left(\mathrm{mm}\right.$ year $\left.^{-1}\right)$ & $542( \pm 23)$ & & $545( \pm 54)$ & \\
\hline pET year $( \pm \mathrm{SD})\left(\mathrm{mm} \mathrm{year}^{-1}\right)$ & $790( \pm 24)$ & & $754( \pm 41)$ & \\
\hline CWB veg. per. $\left( \pm\right.$ SD) $\left(\mathrm{mm}\right.$ year $\left.^{-1}\right)$ & $-104( \pm 112)$ & & $-105( \pm 134)$ & \\
\hline CWB year $\left( \pm\right.$ SD) $\left(\mathrm{mm} \mathrm{year}^{-1}\right)$ & $-7( \pm 139)$ & & $114( \pm 208)$ & \\
\hline
\end{tabular}

Besides from stand characteristics sample sizes, growth and climate are reported. Site index $h_{\mathrm{o}}$ refers to yield table Assmann and Franz (1963) for Norway spruce and Schober (1967) for European beech. Climate conditions refer to mean annual temperature $\left(T\right.$, $\left.{ }^{\circ} \mathrm{C}\right)$, precipitation $(P$, $\mathrm{mm}$ year $\left.^{-1}\right)$, potential evapotranspiration (pET, $\mathrm{mm} \mathrm{year}^{-1}$ ) and climatic water balance (CWB, mm year ${ }^{-1}$ ) during vegetation period (veg. per.) and per year (year)

lagged climate effects on growth, lagged Pearson correlations and lagged GLK scores $(-5, \ldots+5)$ were also calculated.

The approach to question (iii) was as follows: A subset of the experimental plot FRE 813/1 was maintained under ozone fumigation from spring 2000 to the autumn of 2007 (Matyssek et al. 2010), with access by a canopy crane and scaffolding to study stress effects on adult Norway spruces and European beeches. The center of the ozone fumigation was represented by a group of beech trees together with neighboring spruces. The ozone fumigation was conducted by means of the Kranzberg Ozone Fumigation Experiment (KROFEX), representing a free-air methodology of ozone release (see Werner and Fabian 2002). The size-growth data from trees under long-term ozone fumigation $\left(2 \times \mathrm{O}_{3}\right)$ was applied. Analogously, data from reference stands with ambient ozone levels $\left(1 \times \mathrm{O}_{3}\right)$ was collected to identify any difference in the size-asymmetry of growth allocation between cohorts with and without additional $\mathrm{O}_{3}$ impact. In contrast to the approach used for question (i) and (ii), the diameter at breast height $(d)$ was used at the beginning of the fumigation period, and the periodical annual diameter increment (id) was used from 2000 to
2007. Table 3 shows the complete dataset used for these analyses. Stand characteristics are similar to those given in Table 2, as the trees exposed to $1 \times \mathrm{O}_{3}$ and $2 \times \mathrm{O}_{3}$ conditions are on a plot in the same stand.

In order to reveal any effect of ozone on the species specific size-growth relationship, an ordinary least square regression (OLS) was fitted, describing the relationship between the variables id and $d$ discretely for each distinct group. For identifying the group affiliation, the effect of ambient or doubled ozone was included as a dummy variable on the intercept and the slope of the linear model, which described the diameter-diameter increment relationship (see Eq. 6). The following model was applied:

id $=\left(g_{0}+g_{1}\right.$ ozone $)+\left(g_{2}+g_{3}\right.$ ozone $) \times d+\varepsilon$

with diameter increment id (mm), diameter $d(\mathrm{~mm})$, ozone as a factor for the effect of the ozone treatment $(0=$ ambient ozone, $1=$ double ambient ozone $)$, regression coefficients $g_{0}$ to $g_{3}$, and random error $\varepsilon$.

Due to the aim of analyzing effects of double ambient ozone, the group $1 \times \mathrm{O}_{3}$ was set to zero to serve as a reference. The coefficients, $g_{1}$ and $g_{3}$, of each of the dummy variables, depicted as the ozone variable, represent 
Table 3 Characteristics of the sample stands under ambient and double ambient ozone (applied for answering question iii)

\begin{tabular}{|c|c|c|c|c|}
\hline \multirow[t]{2}{*}{ Variable } & \multicolumn{2}{|c|}{ Ambient ozone $\left(1 \times \mathrm{O}_{3}\right)$} & \multicolumn{2}{|c|}{ Double ambient ozone $\left(2 \times \mathrm{O}_{3}\right)$} \\
\hline & N. spruce & E. beech & N. spruce & E. beech \\
\hline First/last year of observation & $2000 / 2007$ & $2000 / 2007$ & $2000 / 2007$ & $2000 / 2007$ \\
\hline Number of trees $(n)$ & 9 & 11 & 14 & 25 \\
\hline Mean diameter $( \pm \mathrm{SD})(\mathrm{mm})$ & $264( \pm 77)$ & $254( \pm 68)$ & $269( \pm 98)$ & $236( \pm 78)$ \\
\hline Min-max diameter $(\mathrm{mm})$ & $143-401$ & $133-372$ & $81-415$ & $133-383$ \\
\hline Diameter growth $( \pm \mathrm{SD})\left(\mathrm{mm} \mathrm{year}^{-1}\right)$ & $3.4( \pm 1.5)$ & $2.4( \pm 2.4)$ & $3.7( \pm 1.4)$ & $1.5( \pm 1.9)$ \\
\hline Min-max diameter growth $\left(\mathrm{mm}\right.$ year $\left.{ }^{-1}\right)$ & $2-6$ & $0-7$ & $2-6$ & $0-8$ \\
\hline Ozone concentration $( \pm \mathrm{SD})\left(\operatorname{sum}_{00}\right.$ year $\left.^{-1}\right)$ & $226( \pm 22)$ & & $344( \pm 48)$ & \\
\hline $\min -\max$ ozone conc. $\left(\operatorname{sum}_{00}\right.$ year $\left.^{-1}\right)$ & $213-280$ & & $304-455$ & \\
\hline
\end{tabular}

the difference between the double ambient ozone group and the reference ambient ozone group. Thus $g_{0}$ represents the intercept for $1 \times \mathrm{O}_{3}, g_{0}+g_{1}$ the intercept for $2 \times \mathrm{O}_{3}$, and analogously $d_{2}$ the slope for $1 \times \mathrm{O}_{3}$ and $g_{2}+g_{3}$ the slope for $2 \times \mathrm{O}_{3}$. The respective $p$ value reveals the significance of the effect of double ambient ozone exposure on the slope, as well as on the intercept of the size-increment relationship. This method allows for testing $1 \times \mathrm{O}_{3}$ treatment against $2 \times \mathrm{O}_{3}$ treatment concerning intercept and slope simultaneously.

\section{Results}

Dependence of the slope of the size-growth relationship on site conditions

Figure 2 illustrates exemplarily how slopes of size-growth relationships were extracted from the data of long-term plots. The size-growth observations and regression lines are shown for two experimental plots in (a) Norway spruce and (b) European beech with excellent (SAC 607, MIT 101) and low (EGL 72, MIS 25) site fertility but otherwise rather similar stand parameters such as quadratic mean diameter $d_{\mathrm{q}}$ and SDI. We restricted the graphical analysis of the match of observed and modeled size-growth relationships to these examples as a scatter-plot with all 54,888 respective 13,192 observations for spruce and beech (see Table 1) proofed to be useless; however, for the following statistical analysis equivalent data of all experiments and plots was pooled.

The comprehensive scrutiny of the relationship between slope of the diameter-diameter increment relationship and stand characteristics on all plots is based on the following variables displayed in Table 1: stand age (A), dominant height at the age of 100 years $\left(h_{\mathrm{o}}\right)$, SDI as defined by Reineke (1933) and calculated with the species specific allometric exponents by Pretzsch and Biber (2005), and quadratic mean diameter $\left(d_{\mathrm{q}}\right)$. Regression analysis revealed a significant effect of $h_{\mathrm{o}}$, SDI and $d_{\mathrm{q}}$ on the slope $\left(a_{1}\right)$ of the diameter-diameter increment relationship. Key results of the analysis are given in Fig. 3 and Table 4; all variables included in the model were significant to at least $p<0.001$. Figure 3 displays the result of the analysis graphically for (a) Norway spruce and (b) European beech. The relationship between diameter increment and diameter is shown to be dependent on the site index $\left(h_{\mathrm{o}}\right)$ when all other influencing variables are kept constant. For the independent variables (SDI, $d_{\mathrm{q}}$ ) species specific mean values as given in Table 1 were inserted. Using Eq. 3, the slope $a_{1}$ was calculated and the respective intercept $a_{0}$ was derived by rearranging Eq. 1 to $a_{0}=\mathrm{id}_{\mathrm{q}}-a_{1} \times d_{\mathrm{q}}$ and substituting values for $\mathrm{id}_{\mathrm{q}}$ und $d_{\mathrm{q}}$. The relative growth distribution among trees of different size is reflected by the differing slopes of the lines shown in Fig. 3. The steepest and shallowest lines represent the borderline cases of the site index range in which all observed size-growth relationships lie. The lines in between represent the diameterdiameter increment relationships for stands in the dataset with average top height $\left(h_{\mathrm{o}}=36 \mathrm{~m}\right.$ and $h_{\mathrm{o}}=25 \mathrm{~m}$, in the case of Norway spruce and European beech, respectively). Size-asymmetry increases with increasing site index for both species. On poor sites, the relationships indicate a tendency towards a size-symmetric size-growth relationship. On mediocre and fertile sites perfect size-symmetry or even size-asymmetry is found. Both species' range of size-growth lines includes perfect size-symmetry (lines through the origin with $a_{0}=0$ ).

Effect of drought on the diameter-diameter increment relationship

In the first approach for measuring the effect of drought on the diameter-diameter increment relationship, the annual stem volume growth per hectare (ivol, $\mathrm{m}^{3} \mathrm{ha}^{-1}$ year ${ }^{-1}$ ) of the Norway spruce and European beech pure stand FRE 813/1 was used as a proxy variable for the annual growth conditions. To analyze the size-growth relationship and its 
(a)

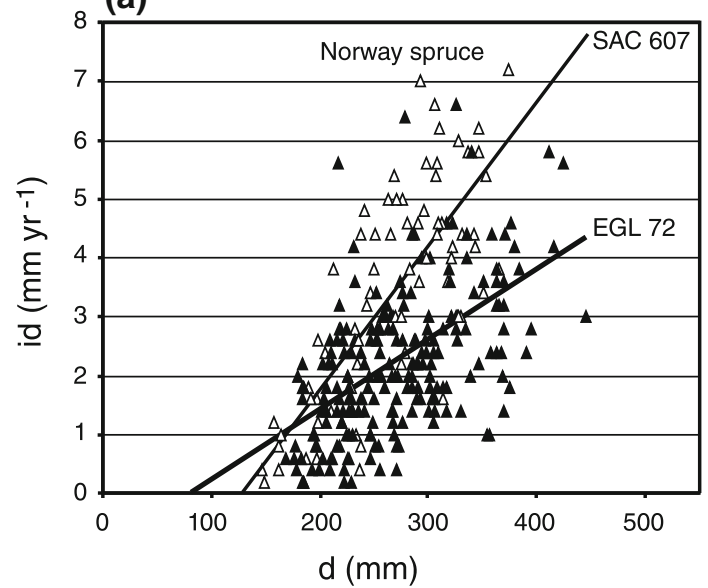

Fig. 2 Relationship between diameter and diameter increment for (a) Norway spruce: Sachsenried 607, plot 7, survey 2001, $d_{\mathrm{q}} 244 \mathrm{~mm}$, $h_{\mathrm{o}} 40.6 \mathrm{~m}$, SDI 1212 (empty triangles; id $=-3.135+0.023 \times d$, $\left.R^{2}=0.593, p<0.001\right)$ and Eglharting 72, plot 2, survey 1950, $d_{\mathrm{q}}$ $252 \mathrm{~mm}, \quad h_{\mathrm{o}} 31.4 \mathrm{~m}$, SDI 1316 (filled triangles; id $=-$ $\left.0.941+0.012 \times d, R^{2}=0.202, p<0.001\right)$ and for (b) European

\section{(a)}

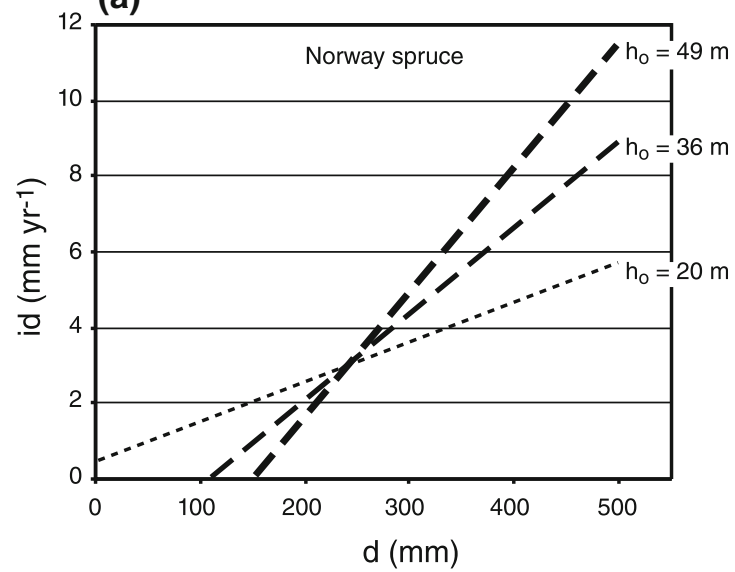

Fig. 3 Relationship between stem diameter and diameter increment for poorest, medium and best site conditions for the species (a) Norway spruce and (b) European beech. For each species, we show the diameter-diameter increment relationship for sites with

dependency on the annual growth conditions, the relationship between the annual slopes of the diameter-diameter increment relationships and respective annual growth was linearly fitted. The resulting parameters of the linear regression (Eq. 5) are reported in Table 5. For the periods 1972-1980 and 1999-2007 a significant increase of the diameter-diameter increment relationship slope $e_{1}$ was found with increasing absolute stand growth rate (ivol) (Fig. 4). This indicates that Norway spruce (a) and European beech (b) reveal a tendency towards size-asymmetry (steep slopes of diameter-diameter increment relationship) in years of high growth rates and rather size-symmetric (b)

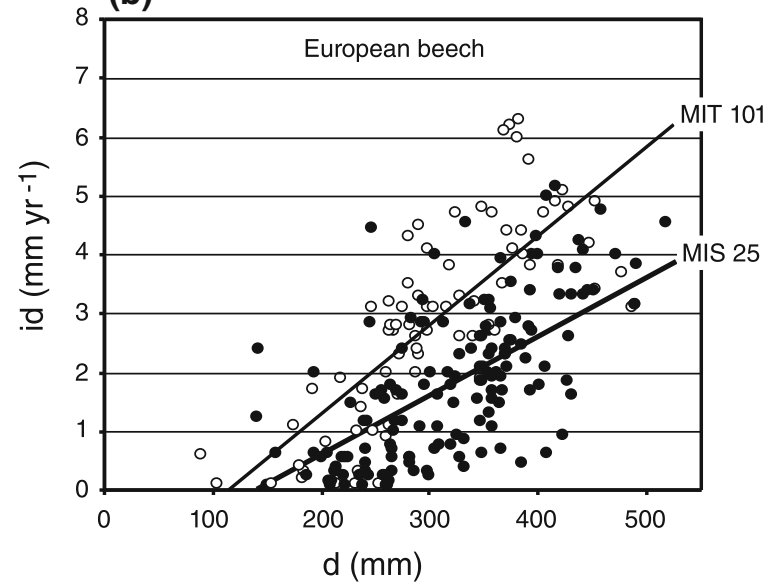

beech: Mitterteich 101, plot 2, survey 1960, $d_{\mathrm{q}} 305 \mathrm{~mm}, h_{\mathrm{o}} 37.1 \mathrm{~m}$, SDI 733 (empty circles; id $=-1.487+0.014 \times d, R^{2}=0.595$, $p<0.001)$ and Mittelsinn 25, plot 1 , survey $1968, d_{\mathrm{q}} 311 \mathrm{~mm}, h_{\mathrm{o}}$ $27.5 \mathrm{~m}$, SDI 876 in case of beech (filled circles; id $=-$ $\left.1.418+0.010 \times d, R^{2}=0.401, p<0.001\right)$

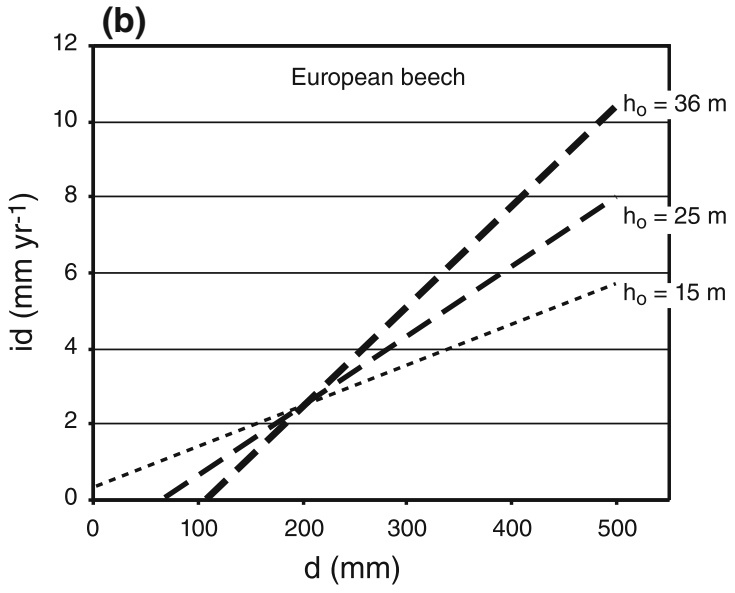

highest fertility (steepest line), medium fertility (medium line), and lowest site fertility (shallow line). For both species applies, that the steepness of the slope, i.e. the asymmetry of the size-growth relationship increases from poor to fertile sites

size-growth relationship (shallow slopes of the $d$-id relationship) in years of low growth rates. The tendency towards size-asymmetry (steeper slopes) under beneficial growth conditions and size-symmetry (shallower slopes) under unfavorable conditions which we revealed along an ecological gradient (see "Dependence of the slope of the size-growth relationship on site conditions") obviously applies also for the temporal change of growth along a time series with beneficial and unfavorable years.

In the second approach for measuring the effect of drought on the diameter-diameter increment relationship, the analysis was repeated, this time making use of the mean 
Table 4 Parameters $( \pm$ SE) and coefficient of determination for the linear model (Eq. 3) of slope $a_{1}$ in dependency on top height at age $100\left(h_{\mathrm{o}}\right)$, stand density index according to Reineke (SDI), and quadratic mean diameter $\left(d_{\mathrm{q}}\right)$

\begin{tabular}{llll}
\hline Parameter & Variables & N. spruce & E. beech \\
\hline$c_{0}$ & & $0.012( \pm 0.004)$ & $0.003( \pm 0.006)$ \\
$c_{1}$ & $h_{\mathrm{o}}(\mathrm{m}) / 1,000$ & $0.771( \pm 0.120)$ & $0.840( \pm 0.129)$ \\
$c_{2}$ & SDI $\left(\right.$ trees $\left.\mathrm{ha}^{-1}\right) /$ & $0.005( \pm 0.003)$ & $0.009( \pm 0.004)$ \\
& 1,000 & & \\
$c_{3}$ & $d_{\mathrm{q}}(\mathrm{mm}) / 1,000$ & $-0.093( \pm 0.008)$ & $-0.072( \pm 0.005)$ \\
$R^{2}$ & & 0.37 & 0.72 \\
$p$ value & & $<0.001$ & $<0.001$ \\
\hline
\end{tabular}

In order to keep the decimal places of parameters $c_{0}$ to $c_{3}$ low, the independent variables $\left(h_{\mathrm{o}}\right.$, SDI and $\left.d_{\mathrm{q}}\right)$ were divided by 1,000 before being applied in the regression

annual temperature $(T)$, precipitation $(P)$, potential evapotranspiration (pET), and climatic water balance (CWB) as independent variables. The climate conditions are shown in Fig. 5. The correlation between these annual weather variables was analyzed, along with the slope $e_{1}$ of the diameter-diameter increment relationship in the respective years. Table 6 shows that the effect of high temperature on the slope is negative, and the effect of high precipitation is positive regardless of tree species. Although, these relationships are only partially significant, they do indicate that sufficient water supply and moderate temperatures increase the size-asymmetry of growth and resource partitioning in the stand. By contrast, drought and high temperatures flatten the $d$-id relationship and increase the tendency towards size-symmetric growth and resource partitioning among the trees in a stand. For spruce the analysis reveals that it reacts more sensitive to drought as indicated by the significant correlation between $T$ and slope. In addition, analysis of the Gleichlaeufigkeit reveals that the year-toyear agreement between the analyzed slope and $P$ or CWB is higher than for $T$ or pET. Lagged effects of the correlation ( $r$ ) or the Gleichlaeufigkeit (GLK), computed by shifting the climate data $(-5, \ldots+5)$ were not found. Correlation and Gleichlaeufigkeit score between the slope and weather variables in different years are lower.

Figure 6 displays the reaction pattern for the extremely dry/warm year 1976 in contrast to the rather moist/temperate year 1978. In the case of Norway spruce, the slopes

Table 5 Parameters $( \pm \mathrm{SE})$ and coefficient of determination for the linear model of slope $e_{1}$ of the annual diameter-diameter increment relationship in dependency on annual volume increment (ivol) (Eq. 5)

\begin{tabular}{|c|c|c|c|c|c|}
\hline \multirow[t]{2}{*}{ Parameters } & \multirow[t]{2}{*}{ Variables } & \multicolumn{2}{|l|}{ N. spruce } & \multicolumn{2}{|l|}{ E. beech } \\
\hline & & $1972-1980$ & 1999-2007 & 1972-1980 & 1999-2007 \\
\hline$f_{0}$ & & $-0.016( \pm 0.009)$ & $-0.006( \pm 0.010)$ & $-0.030( \pm 0.013)$ & $0.002( \pm 0.004)$ \\
\hline$f_{1}$ & ivol $\left(\mathrm{m}^{3} \mathrm{ha}^{-1}\right.$ year $\left.^{-1}\right) / 100$ & $0.246( \pm 0.071)$ & $0.104( \pm 0.036)$ & $1.071( \pm 0.244)$ & $0.058( \pm 0.015)$ \\
\hline$R^{2}$ & & 0.63 & 0.48 & 0.70 & 0.64 \\
\hline$p$ value & & $<0.01$ & $<0.05$ & $<0.01$ & $<0.01$ \\
\hline
\end{tabular}

In order to keep the decimal places of parameters $c_{1}$ low, the independent variable ivol was divided by 100 before inserting in the regression

(a)

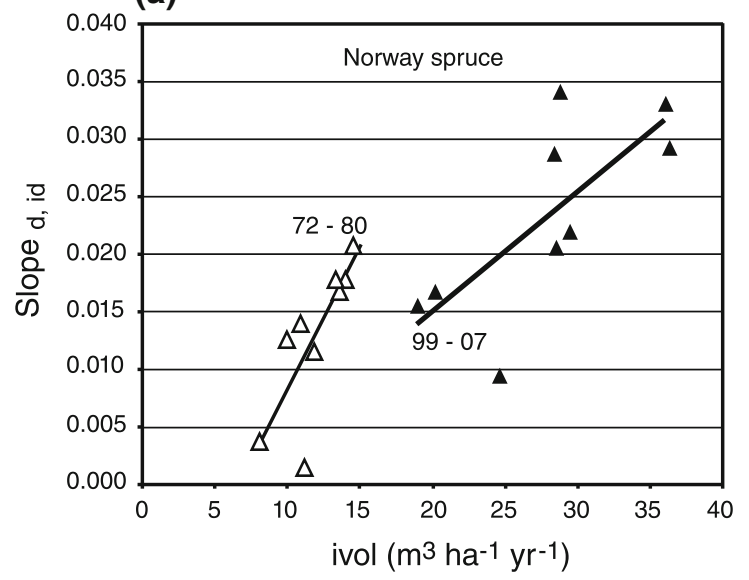

Fig. 4 Slope of the diameter-diameter increment relationship for (a) Norway spruce and (b) European beech trees over the annual stand volume growth (ivol). The OLS fit is separately shown for the (b)

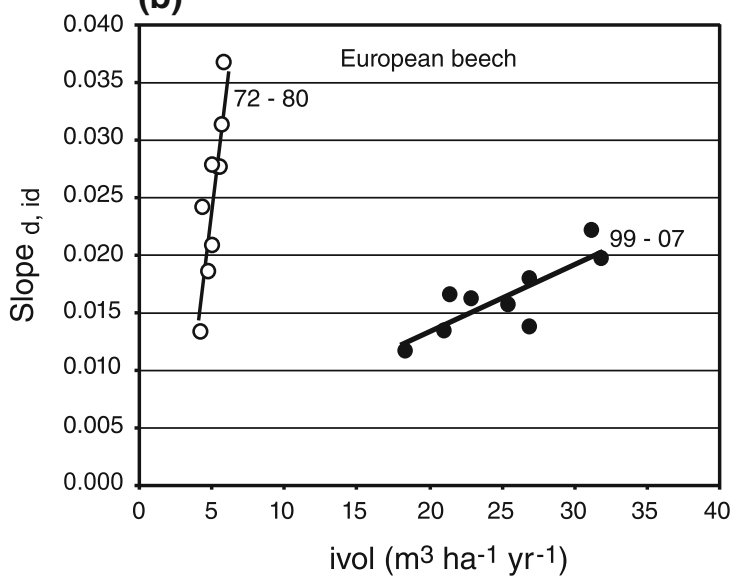

periods 1972-1980 (empty symbols) and 1999-2007 (filled symbols). The linear regressions are significant at the 0.05 level in case of spruce and at the 0.01 level in case of beech, respectively 
(a)

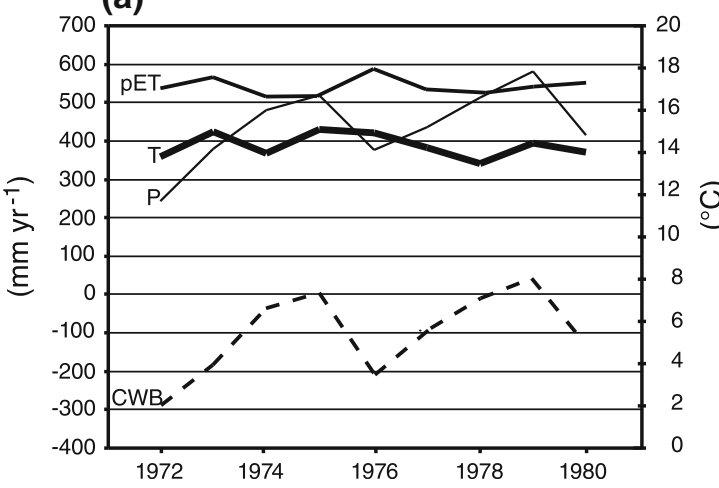

Fig. 5 Annual mean temperature $\left(T,{ }^{\circ} \mathrm{C}\right)$, precipitation $(P$, $\mathrm{mm}$ year $\left.^{-1}\right)$, potential evapotranspiration $\left(\mathrm{pET}, \mathrm{mm} \mathrm{year}^{-1}\right.$ ) and climatic water balance (CWB, mm year ${ }^{-1}$ ) during growing season (b)

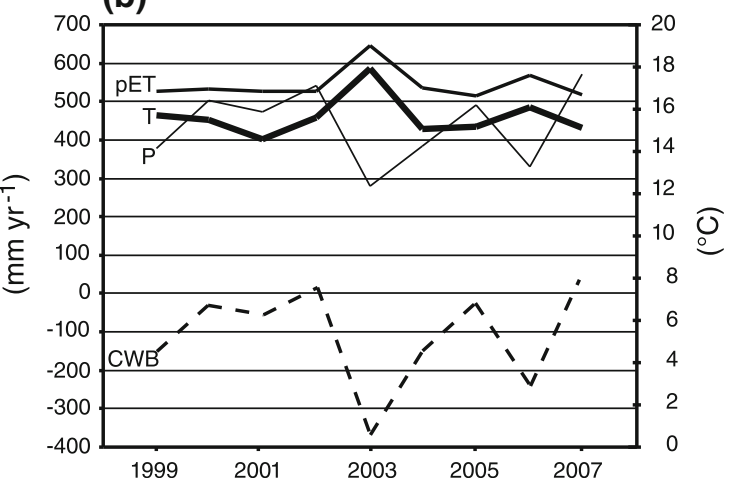

recorded by the DWD weather station Weihenstephan/Dürnast. Climate conditions are presented for the observation periods (a) 1972-1980 and (b) 1999-2007
Table 6 Pearson correlation coefficient $r$ and Gleichlaeufigkeit GLK calculated between the slope $e_{1}$ of the annual diameter-diameter increment relationship and the annual climate variables during growing period (MaySeptember) * $r$ is significant at the 0.05 level

\begin{tabular}{|c|c|c|c|c|c|}
\hline \multirow[t]{3}{*}{ Climate variables } & \multirow{3}{*}{$\begin{array}{l}\text { Pearson correlation } r \\
\text { Gleichlaeufigkeit } G L K\end{array}$} & \multicolumn{4}{|l|}{ Slope $_{\text {id, } d}$} \\
\hline & & \multicolumn{2}{|l|}{ N. spruce } & \multicolumn{2}{|l|}{ E. beech } \\
\hline & & $1972-1980$ & 1999-2007 & $1972-1980$ & 1999-2007 \\
\hline \multirow[t]{2}{*}{$T\left({ }^{\circ} \mathrm{C}\right)$} & $r$ & $-0.704^{*}$ & $-0.597 *$ & -0.087 & -0.465 \\
\hline & $G L K$ & 0.375 & 0.250 & 0.500 & 0.250 \\
\hline \multirow[t]{2}{*}{$P\left(\mathrm{~mm} \mathrm{year}^{-1}\right)$} & $r$ & 0.144 & $0.666^{\circ}$ & $0.631^{\bullet}$ & $0.593^{\circ}$ \\
\hline & $G L K$ & 0.500 & 0.875 & 0.625 & 0.625 \\
\hline \multirow[t]{2}{*}{ pET $\left(\mathrm{mm}\right.$ year $\left.{ }^{-1}\right)$} & $r$ & -0.150 & $-0.678^{*}$ & -0.184 & -0.444 \\
\hline & $G L K$ & 0.375 & 0.125 & 0.500 & 0.375 \\
\hline \multirow[t]{2}{*}{ CWB $\left(\mathrm{mm} \mathrm{year}^{-1}\right)$} & $r$ & 0.159 & $0.703 *$ & $0.604^{\bullet}$ & $0.578^{\bullet}$ \\
\hline & $G L K$ & 0.500 & 0.875 & 0.625 & 0.625 \\
\hline
\end{tabular}

(a)

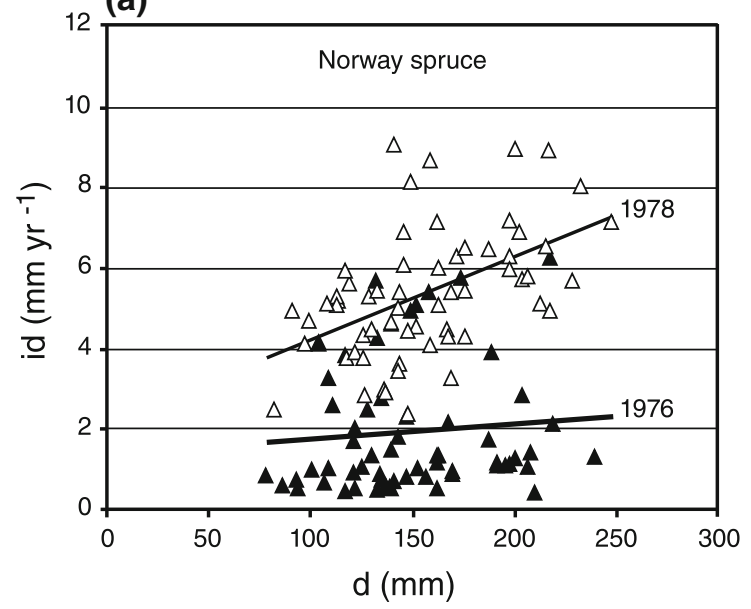

Fig. 6 Annual diameter-diameter increment relationship in years with contrasting climate conditions for (a) Norway spruce and (b) European beech. Year 1976 (filled symbols; OLS fit: Norway spruce $1.368+0.004 \times d, p>0.05$, European beech $-0.683+0.024 \times d$,

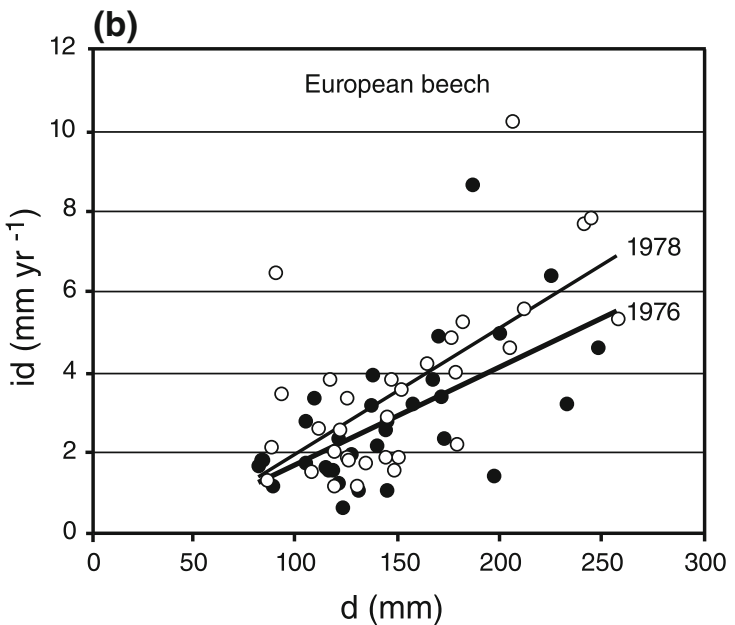

$p<0.001$ ) represents an extremely dry year whereas 1978 (empty symbols; OLS fit: Norway spruce $2.139+0.021 \times d, p<0.001$; European beech $-1.156+0.031 \times d, p<0.001)$ is characterized by excellent growing conditions 
of the diameter-diameter increment relationship in 1976 and 1978 are significantly different at the level $p<0.05$, whereas European beech shows no significant change. Hence, spruce reveals a change in its mode of size-growth relationship; after a rather shallow slope in the dry/warm year 1976, which indicated size-symmetry, the allocation pattern changes within 2 years towards a far more sizeasymmetric size-growth relationship in 1978.

Effect of ozone fumigation on the diameter-diameter increment relationship

The comparison between mean periodic diameter increment of trees with and without ozone fumigation yields neither a different intercept nor a different slope for Norway spruce (Fig. 7a). In the case of European beech, ozone fumigation results in a significantly shallower slope (slope $_{1 \times \mathrm{O}_{3}}\left(g_{3}\right)=0.033$; slope $\left._{2 \times \mathrm{O}_{3}}\left(g_{3}+g_{4}\right)=0.011\right) \quad$ of the diameter-diameter increment relationship (Fig. 7b). The difference is significant to the level $p<0.05$. This indicates that ozone stress reduces the growth of dominant European beeches more than their smaller neighbors; so the latter are the relative winners of the ozone stress. The straight line representing the size-growth relationship changes from size-asymmetry under ambient ozone exposition $\left(1 \times \mathrm{O}_{3}\right)$ to size-symmetry under ozone stress $\left(2 \times \mathrm{O}_{3}\right)$.

Finally, the combined effect of summer drought and ozone on the annual diameter-diameter increment relationship was analyzed for 2003. Figure 8 shows the annual diameter increment over the initial diameter of trees

(a)

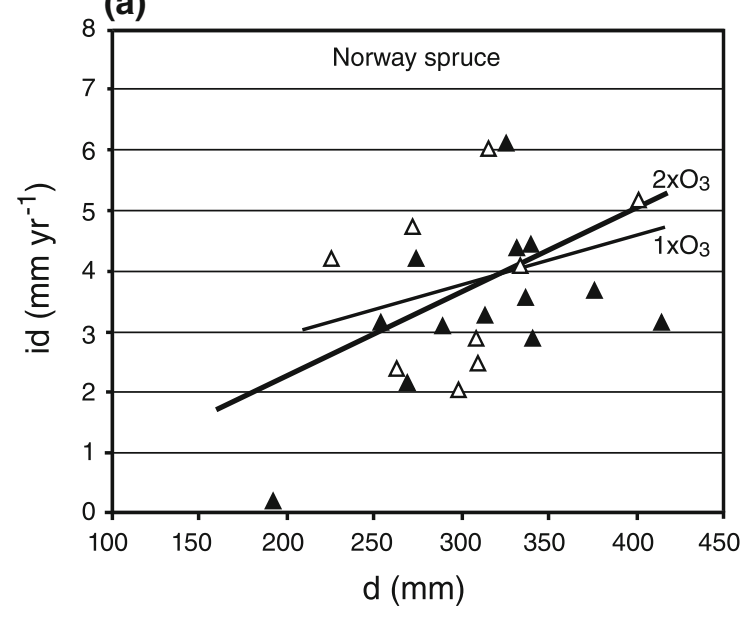

Fig. 7 Mean annual diameter increment in the $\mathrm{O}_{3}$ fumigation period 2000-2007 over initial diameter without ozone fumigation $\left(1 \times \mathrm{O}_{3}\right.$ : empty symbols $)$ and with double ambient ozone fumigation $\left(2 \times \mathrm{O}_{3}\right.$ : filled symbols) for (a) Norway spruce and (b) European beech trees. The diameter-diameter increment relationship is represented by thin lines in case of $1 \times \mathrm{O}_{3}$, and by bold lines in case of $2 \times \mathrm{O}_{3}$. The OLS exposed to $1 \times \mathrm{O}_{3}$ and $2 \times \mathrm{O}_{3}$ conditions in 2003. Again, it was found that ozone fumigation reduces the slope considerably, which is equivalent to a shift from sizeasymmetric to a more size-symmetric size-growth relationship under combined drought and ozone stress in 2003. Norway spruce shows a stronger flattening of the slope under ozone fumigation than European beech. For spruce, the flattening of the slope is significant (Fig. 8a) whereas beech shows no significant change (Fig. 8b; Table 7). This suggests that spruce reacts more sensitively to $2 \times \mathrm{O}_{3}$ in years with poor water supply than beech. Figure $8 \mathrm{a}$ displays one high value of diameter increment $(11.2 \mathrm{~mm})$. At first glance this value seems to suggest a possible outlier. However, as the diameter increments are based on monthly read records of permanent increment tapes, it was possible to correlate this annual increment against the increment in the previous and successive years and verify its accuracy.

\section{Discussion}

The results of this study contribute to the theory of resource and growth partitioning in tree communities, as well as to a better understanding of the structural stand dynamic of forest stands under different growing conditions. Similar analyses are available to some degree for herbaceous stands (Canell and Grace 1993; Müller et al. 2000; Weiner and Thomas 1986), somewhat more scarcely so for juvenile woody stands (Ammer 1996; Hara 1993; Kuijk et al. 2008; Thomas and Weiner 1989; Weiner and Thomas 1986) and are extremely limited for mature forest stands (Wichmann (b)

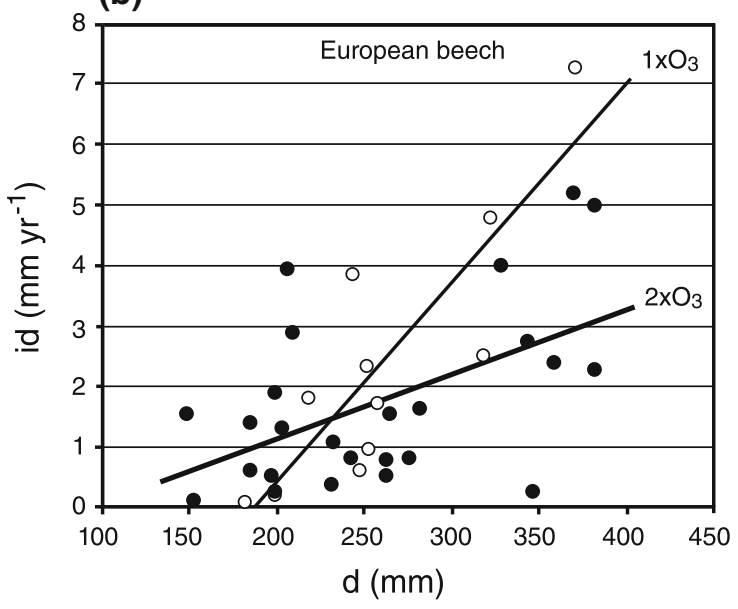

fit (Eq. 6) yielded in $\operatorname{id}_{99-07}=(1.238-2.182 \times$ ozone $)+(0.008+$ $0.005 \times$ ozone $) \times d_{99} \quad(p<0.05)$ for spruce and $\mathrm{id}_{99-07}=$ $(-6.254+5.210 \times$ ozone $)+(0.033-0.002 \times$ ozone $) \times d_{99}(p<$ $0.001)$ for beech. In case of beech the effect of ozone on intercept and slope is significant at the level 0.05 
(a)

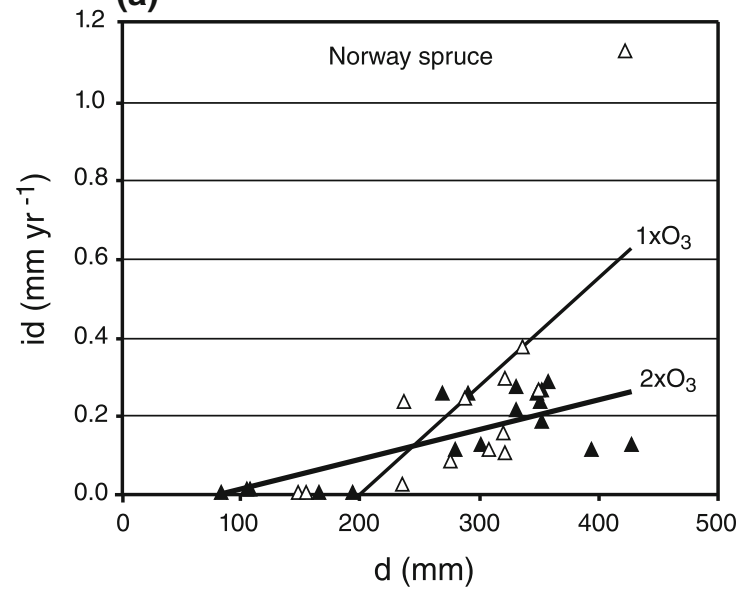

Fig. 8 Annual diameter increment in 2003 over initial diameter of (a) Norway spruce and (b) European beech trees without ozone fumigation $\left(1 \times \mathrm{O}_{3}\right.$ : empty symbols $)$ and with double ambient ozone fumigation $\left(2 \times \mathrm{O}_{3}\right.$ : filled symbols $)$. The OLS fit of the diameter- (b)

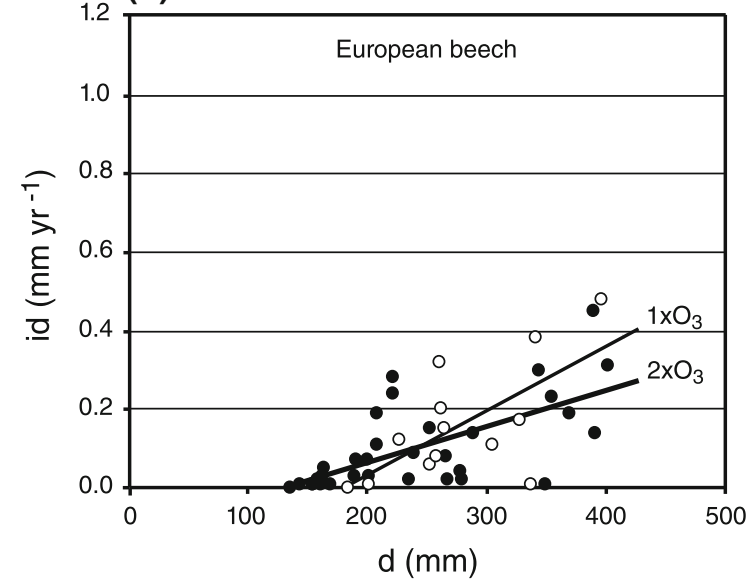

diameter increment relationship is represented by thin lines in case of $1 \times \mathrm{O}_{3}$, and by bold lines in case of $2 \times \mathrm{O}_{3}$. For statistical results see Table 7

Table 7 Fit of the model for the diameter-diameter increment relationship (Eq. 6) for Norway spruce and European beech in the dry year 2003

\begin{tabular}{|c|c|c|c|c|c|}
\hline \multirow[t]{2}{*}{ Parameters } & \multirow[t]{2}{*}{ Variables } & \multicolumn{2}{|l|}{ N. spruce } & \multicolumn{2}{|l|}{ E. beech } \\
\hline & & Value $( \pm \mathrm{SE})$ & $p$ value & Value $( \pm \mathrm{SE})$ & $p$ value \\
\hline$g_{0}$ & & $-5.613( \pm 1.604)$ & $<0.01$ & $-2.893( \pm 1.308)$ & $<0.05$ \\
\hline$g_{1}$ & Ozone & $4.988( \pm 1.889)$ & $<0.05$ & $1.742( \pm 1.416)$ & $>0.05$ \\
\hline$g_{2}$ & $d(\mathrm{~mm})$ & $0.028( \pm 0.005)$ & $<0.001$ & $0.016( \pm 0.005)$ & $<0.01$ \\
\hline$g_{3}$ & Ozone & $-0.020( \pm 0.006)$ & $<0.01$ & $-0.007( \pm 0.005)$ & $>0.05$ \\
\hline$R^{2}$ & & 0.50 & & 0.41 & \\
\hline
\end{tabular}

The effect of double ambient ozone is considered by the bivariate factor ozone $\left(0=1 \times \mathrm{O}_{3} ; 1=2 \times \mathrm{O}_{3}\right)$

2001, 2002). In this study, forest stands which were under survey for decades to centuries were analyzed, where the growth of individuals had been measured continually without affecting the stand growth and structure in the course of taking the measurements. The stands cover a broad range of ages, stand phases and site conditions, and are selected along an ecological gradient for question (i), to reflect a time series for question (ii), and with differing stress conditions for question (iii).

In all three reported evaluations the slope of the relationship between size and size growth shows a clear dependence on the prevailing limitation. The general reaction pattern, which can be assumed as a preliminary working hypothesis, is shown schematically in Fig. 9. On poor sites under drought or ozone stress the slope is shallow, indicating that the difference between the growth of small and tall trees is smaller than on fertile sites or on sites without stress. In stands with unfavorable growing conditions, size growth increases at a rate less than proportional to plant size. Under mediocre site conditions size growth increases proportionally to tree size, resulting in size-

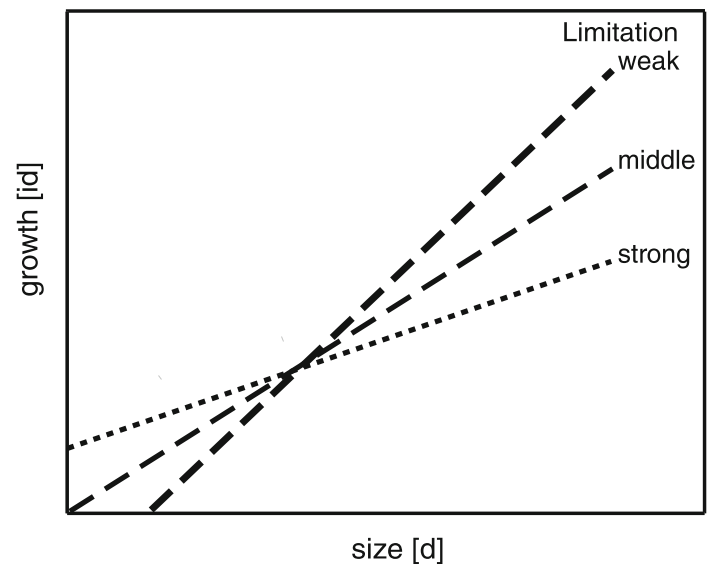

Fig. 9 Effect of resource limitation on the relationship between size and growth in schematic representation

symmetry. Optimal resource supply results in disproportional increase of size growth with tree size, i.e. sizeasymmetric size-growth relationship (Fig. 9). 
This general reaction pattern is in accordance with, among others, the empirical findings of Wichmann (2001, 2002) in adult forest stands, Kuijk et al. (2008) for tree dominated communities in the succession phase, and Thomas and Weiner (1989) and Weiner and Thomas (1986) for herbaceous stands, as well as by model scenarios from Hara (1993) for forest stands. In terms of the combined effect of ozone and drought stress, our results match the findings of Löw et al. (2006), who shows that drought counteracts the impact of $\mathrm{O}_{3}$ in adult beech by stomatal closure.

For causal explanation it is speculated that under favorable site conditions and without additional stress, dominant trees profit disproportionally as they make use of their privileged access to light. By pre-empting light they raise their own growth rate and impede the growth of their smaller neighbors. In contrast, under unfavorable conditions, where growth is restricted by limitation of water or mineral nutrient supply, by drought or by ozone stress, dominant trees can make less use of their superior position. For this reason, the relationship between size and size growth becomes less pronounced. In the sense of Darwinian fitness, the relative advantage over competitors rather than the absolute growth rate is decisive for success under selective pressure and fitness. Hence, the analyzed relationship between size and size growth is an indicative proxy for competitiveness, as it explicitly reflects this relative difference between the growth of small and large members of a community.

The relationship between plant size and resource supply (water, light, mineral nutrients) is of particular interest but difficult to measure accurately. Therefore, we used the distribution of diameter increment among the trees in a stand and the relationship between diameter and diameter increment (intercept, slope, linearity or non-linearity of the size-growth relationship) as a proxy for the size-resource relationship. This analysis of the size-growth relationship represents a first step towards an explanation of sitedependency of the biomass and resource distribution between the trees of a stand. The inference from sizegrowth relationship to size-resource relationship requires further investigation (Schwinning and Weiner 1998). Long-term experiments, especially when covering various site conditions, can provide considerable information for further research in this area. In herbaceous plant populations, where most of the empirical and theoretical research exists to date, it is rarely possible to measure the spatial occupation of individuals and to record growth of survivors and losses of individuals accurately without greatly disturbing them and the stand structure (Thomas and Weiner 1989; Weiner and Thomas 1986). By contrast, the particular spatial dimension of forests provides a unique opportunity to analyze the individual plant growth, biomass distribution between trees of different size and their mortality.

The reason for applying the diameter-diameter increment relationship instead of volume increment-tree volume is that the former method's values are directly derived from measurement, while volume increments and volume are derived variables and subject to the inaccuracies in the chosen form factors and height measurements. Hara (1993) states that both the growth and size-structure dynamics of stem diameter and stem volume are almost parallel, which is also expressed by the proportional relationship between the relative growth rates of diameter and volume, $\mathrm{id} / d \times 3 \cong$ increment in volume/volume (Prodan 1965, pp. 455-456).

So far, in this study the site conditions are reflected by factors such as the stand site index and the degree of stress impact by the amount of annual stand volume growth. These factors are represented by proxy variables, as direct measurements of site variables were not available for most of the long-term plots. Furthermore, the mode of competition is indicated by the size $[d]$-growth [id] relationship rather than by the resource distribution between the plants.

\section{Conclusions}

The consequences of these findings concern silvicultural treatment: improved resource supply leads to a steeper slope of the relationship between size and size growth, and a lower relative share of resources that the subdominant and understory trees can utilize for growth. This means that the slope also reflects the structural diversity of a stand: Shallow relationships between size and size growth on poor sites indicate rather similar growth conditions for small and tall members of the population. Steep slopes indicate that dominant neighbors consume much more of the available resource than their smaller neighbors, and this superiority of the dominate trees can increase self-thinning in the understory. Under ceteris paribus conditions (same stand density, age etc.) structural diversity increases when resource supply becomes scarce (Assmann 1970). On rich sites, such as those with dominating light limitation, growth can be more easily concentrated on a limited number of selected trees. However, on poor sites understory trees still grow at a rate proportional to their size, and vertical structure is more stable on such latter sites. On these sites, water and nutrients are the limiting factors and restrict the competition and superiority of dominant trees, which is overwhelming on rich sites.

The dependency of the size-growth relationship on the prevailing limitation also applies to the modeling of competition: As long as models are developed and applied for a narrow range of site conditions the limitation and the mode of competition and size-growth relationship also varies 
within a small range so that the prognosis of growth, growth reaction after thinning or underplanting is realistic. However, as future models should be applicable for a broader range of site conditions (Pretzsch et al. 2008), such as for predicting growth reactions on thinning, underplanting, fertilization on different sites and possibly also for predicting growth reaction under climate change (shift from light limitation to below-ground resource limitation), then it seems important to differentiate between different modes of competition and size-growth relationships. In light of these results, a generalization of the function for the growth reduction in individual-tree models is not appropriate (Pretzsch and Biber 2010). Compared to rich sites, individuals of similar size which are impacted by the same competition index (CI) still grow better on poor sites. Thus, the so far site independent reduction function applied in individual-tree models (e.g., Biging and Dobbertin 1995) requires site-dependency. For this reason, an improvement of existing growth models and a more flexible algorithm for reduction of the potential growth by considering different trajectories of modifier-CI relationships depending on the mode of competition is recommended.

Acknowledgments The authors would like to thank Ulrich E. Lüttge, Rainer Matyssek, and anonymous reviewers for their helpful comments on the manuscript. The research was supported by Deutsche Forschungsgemeinschaft by funding the Sonderforschungsbereich SFB 607 "Growth and Parasite Defense" and by the Bavarian State Ministry for Nutrition, Agriculture and Forestry funding the project W 07 "Long-term experimental plots for forest growth and yield research". Thanks are also given to the German Weather Service (Deutscher Wetterdienst, DWD) and Ulrich Kern for the graphical artwork. All of the experiments conducted in this study complied with the current applicable German laws.

Open Access This article is distributed under the terms of the Creative Commons Attribution Noncommercial License which permits any noncommercial use, distribution, and reproduction in any medium, provided the original author(s) and source are credited.

\section{References}

Ammer Ch (1996) Konkurrenz um Licht-Zur Entwicklung der Naturverjüngung im Bergmischwald. Forst. Forschungsber. München, Forstwiss. Fak. der Univ. München, Nr. 158, 211 p

Assmann E (1970) The principles of forest yield study. Pergamon Press, Oxford 506

Assmann E, Franz F (1963) Vorläufige Fichten-Ertragstafel für Bayern. Forstl Forschungsanst München, Inst Ertragskd, 104 p

Beierkuhnlein C, Foken Th (2008) Klimawandel in Bayern. Auswirkungen und Anpassungsmöglichkeiten. Bayreuther Forum Ökologie, University Bayreuth, vol 113, 501p

Biging GS, Dobbertin M (1995) Evaluation of competition indices in individual tree growth models. For Sci 41:360-377

Bugmann H, Grote R, Lasch P, Lindner M, Suckow F (1997) A new forest gap model to study the effects of environmental change on forest structure and functioning. In: Mohren GMJ, Kramer K,
Sabaté S (eds) Impacts of global change on tree physiology and forest ecosystems. Forestry sciences. Kluwer Academic Publishers, Wageningen, pp 255-261

Bundesministerium für Ernährung, Landwirtschaft und Verbraucherschutz (2005) Die zweite Bundeswaldinventur-BWI2, Der Inventurbericht. Bundesministerium für Ernährung, Landwirtschaft und Verbraucherschutz, Bonn, 231p

Canell MGR, Grace J (1993) Competition for light: detection, measurement, and quantification. Can J For Res 23:1969-1979

Eckstein D, Bauch J (1969) Beitrag zur Rationalisierung eines dendrochronolgischen Verfahrens und zur Rationalisierung seiner Aussagesicherheit. Forstwissenschaftliche Centralblatt $88: 230-250$

Elling W (1993) Immissionen im Ursachenkomplex von Tannenschädigung und Tannensterben. AFJZ 48(2):87-95

FAO (2005) Global Forest Resources Assessment 2005. FAO, Rome

Hara T (1993) Mode of competition and size-structure dynamics in plant communities. Plant Species Biol 8:75-84

Jentsch A, Kreyling J, Beierkuhnlein C (2007) A new generation of climate change experiments: events, not trends. Front Ecol Environ 5(7):365-374

Kreutzer K, Foerst K (1978) Forstliche Wuchsgebietsgliederung Bayerns. Karte 1:1,000,000. Bayerisches Staatsministerium für Ernährung, Landwirtschaft und Forsten

Landsberg JJ (1986) Physiological ecology of forest production. Academic Press, New York, p 198

Löw M, Herbinger K, Nunn AJ, Häberle K-H, Leuchner M, Heerdt C, Werner H, Wipfler P, Pretzsch H, Tausz M, Matyssek R (2006) Extraordinary drought of 2003 overrules ozone impact on adult beech trees (Fagus sylvatica). Trees 20:539-548

Mäkelä A, Hari P (1986) Stand growth model based on carbon uptake and allocation in individual trees. Ecol Mod 33:205-229

Matyssek R, Sandermann H (2003) Impact of ozone on trees: an ecophysiological perspective. Prog Bot 64:349-404

Matyssek R, Agerer R, Ernst D, Munch JC, Oßwald W, Pretzsch H, Priesack E, Schnyder H, Treutter D (2005) The plant's capacity in regulating resource demand. Plant Biol 7:560-580

Matyssek R, Wieser G, Ceulemans R, Renneberg H, Pretzsch H, Haberer K, Löw M, Nunn AJ, Werner H, Wipfler P, Oßwald W, Nikolova P, Hanke D, Kraigher H, Tausz M, Bahnweg G, Kitao M, Dieler J, Sandermann H, Herbinger K, Grebenc T, Blumenröther M, Deckmyn G, Grams TEE, Heerdt C, Leuchner M, Fabian P, Häberle KH (2010) Enhanced ozone strongly reduces carbon sink strength of adult beech (Fagus sylvatica) - resume from the free-air fumigation study at Kranzberg Forest. Environ Pollut 158:2527-2532

Mielikäinen K, Timonen M (1996) Growth trends of Scots pine (Pinus sylvestris, L.) in unmanaged and regularly managed stands in southern and central Finland. In: Spiecker $\mathrm{H}$, Mielikäinen K, Köhl M, Skovsgaard JP (eds) Growth trends in European forests. European Forest Institute, Research Report 5, Springer, Heidelberg, pp 41-59

Müller I, Schmid B, Weiner J (2000) The effect of nutrient availability on biomass allocation patterns in 27 species of herbaceous plants. Perspect Plant Ecol Evol Syst 3(2):115-127

Niklas KJ (1994) Plant allometry. University of Chicago Press, Chicago

Oliver CD, Larson B (1996) Forest stand dynamics. Wiley, New York, p 520

Pretzsch H (1999) Waldwachstum im Wandel, Konsequenzen für Forstwissenschaft und Forstwirtschaft. Forstw Cbl 118:228-250

Pretzsch H (2009) Forest dynamics, growth and yield. From measurement to model. Springer, Berlin 664

Pretzsch H (2010) Zur Verteilung des Zuwachses zwischen den Bäumen eines Bestandes und Abhängigkeit des Verteilungsschlüssels von den Standortbedingungen. Allg Forst J Ztg 181(1/2):4-13 
Pretzsch H, Biber P (2005) A re-evaluation of Reineke's rule and stand density index. For Sci 51:304-320

Pretzsch H, Biber P (2010) Size-symmetric versus size-asymmetric competition and growth partitioning among trees in forest stands along an ecological gradient in central Europe. Can J For Res 40(2):370-384

Pretzsch H, Schütze G (2009) Transgressive overyielding in mixed compared with pure stands of Norway spruce and European beech in Central Europe: evidence on stand level and explanation on individual tree level. Eur J Forest Res 128:183-204

Pretzsch H, Kahn M, Grote R (1998) Die Fichten-Buchen-Mischbestände des Sonderforschungsbereiches „Wachstum oder Parasitenabwehr?" im Kranzberger Forst. Forstwisschaftliches Centralblatt 117:241-257

Pretzsch H, Grote R, Reineking B, Rötzer T, Seifert S (2008) Models for forest ecosystem management: a European perspective. Ann Bot 101:1065-1087

Pretzsch H, Dieler J, Matyssek R, Wipfler P (2010) Tree and stand growth of mature Norway spruce and European beech under long-term ozone fumigation. Environ Pollut 158:1061-1070

Prodan M (1965) Holzmeßlehre. JD Sauerländer's Verlag, Frankfurt am Main, $644 \mathrm{p}$

R Development Core Team (2009) R: A language and environment for statistical computing. R Foundation for Statistical Computing, ISBN 3-900051-07-0, Vienna, Austria

Reineke LH (1933) Perfecting a stand-density index for even-aged forests. J Agr Res 46:627-638

Röhle H (1987) Entwicklung von Vitalität, Zuwachs und Biomassenstruktur der Fichte in verschiedenen bayerischen Untersuchungsgebieten unter dem Einfluß der neuartigen Walderkrankungen. Forstl Forschungsber München 83:122

Schober R (1967) Buchen-Ertragstafel für mäßige und starke Durchforstung. In: Schober R (1972) Die Rotbuche 1971. Schr Forstl Fak Univ Göttingen u Niedersächs Forstl Versuchsanst 43/ 44, JD Sauerländer's Verlag, Frankfurt am Main, 333 p
Schweingruber FH, Albrecht H, Beck M, Hessel J, Joos K, Keller D, Kontic R, Lange K, Niederer M, Nippel C, Spang S, Spinnler A, Steiner B, Winkler-Seifert A (1986) Abrupte Zuwachsschwankungen in Jahrringabfolgen als ökologische Indikatoren. Ber Eidg Anst forstl Versuchswesen, pp 125-179

Schwinning S, Weiner S (1998) Mechanisms determining the degree of size asymmetry in competition among plants. Oecologia 113:447-455

Spiecker H, Mielikäinen K, Köhl M, Skovsgaard JP (eds) (1996) Growth trends in European forests. European Forest Institute, Research Report 5, Springer, Heidelberg, $372 \mathrm{p}$

Thomas SC, Weiner J (1989) Growth, death and size distribution change in an Impatiens Pallida population. J Ecol 77:524-536

Utschig H (1989) Waldwachstumskundliche Untersuchungen im Zusammenhang mit Waldschäden. Auswertung der Zuwachstrendanalyseflächen des Lehrstuhles für Waldwachstumskunde für die Fichte (Picea abies (L.) Karst.) in Bayern. Forstl Forschungsber München 97, 198p

van Kuijk M, Anten NPR, Oomen RJ, van Bentum DW, Werger MJA (2008) The limited importance of size-asymmetric light competition and growth of pioneer species in early secondary forest succession in Vietnam. Oecologia 157:1-12

Weiner J (1990) Asymmetric competition in plant populations. Trends Ecol Evol 5(11):360-364

Weiner J, Thomas SC (1986) Size variability and competition in plant monocultures. Oikos 47:211-222

Werner H, Fabian P (2002) Free-air fumigation of mature trees-a novel system for controlled ozone enrichment in grown-up beech and spruce canopies. Environ Sci Pollut Res 9:12-117

Wichmann L (2001) Annual variations in competition symmetry in even-aged Sitka Spruce. Ann Bot 88:145-151

Wichmann L (2002) Competition symmetry. Chapter 7. In: modelling the effects of competition between individual trees in forest stands. $\mathrm{PhD}$ thesis, University of Forestry, Copenhagen, pp 67-77 